\title{
Analysis Of Child Labour Practices In Urban And Rural Communities In Cross River State, Nigeria
}

\author{
Stephen Adi Odey \\ Department of Sociology, University of Calabar, \\ Cross River state, Nigeria. \\ Ngutor Sambe \\ Department of Sociology, University of Mkar, \\ Mkar, Benue state, Nigeria.
}

\begin{abstract}
The study was aimed at identifying child labour practices existing in urban and rural areas in Cross River state. The study utilized survey design while cluster random sampling and purposive sampling technique was used to select samples, questionnaires and key informant interview were deployed for data collection. The analysis of data involved use of percentages and transcription of views of the key informants. The study discovered that child labour practices in urban areas of Cross River state include domestic work, street hawking, and shop/store operating, blue-collar laboring, plate washing in restaurants, car washing and bus conducting. In rural communities, child labour the practices are kiosk operating, palm wine tapping and sales. The findings have also shown that in urban communities, nearly half of the respondents are paid for their services while in rural areas most of the children are not paid for their services. The amount of money paid to the child labourers in the urban areas ranges mostly between $\mathrm{N300- \textrm {N } 5 0 0}$ while in the rural communities, majority of respondents receive below N200. The category of people engaging children as child labourers in urban areas, are mostly business owners/operators while in rural areas, parents are the group that uses children as child labourers the most. Recommendations for controlling child labour in urban areas include execution of child right laws, creation of awareness and prosecution of people who engage children in labourous practices. In rural areas, creation of awareness, poverty reduction and execution of child right laws was recommended.
\end{abstract}

Key Words: Child Labour, Child Right, Rural and Urban Communities, Paid Jobs, Domestic Servants.

\section{INTRODUCTION}

Labour is one of the greatest assets behind development of all societies; however child labour seem to have adverse consequences on development of society (Moser 1996). Child labour is a social phenomenon that is rampant in developing countries such as Nigeria as 15 million children under the age of 14 are working as child labourers in rural and urban area in the country (Bass 2004; UNICEF 2006). Available data indicates that in Nigeria, approximately 53 percent of children eligible for primary education are subjected to child labour while an estimated 81.12 percent of children qualified to be in secondary school are actually not schooling or seem to be combining work with schooling due child labouring activities (Okafor 2010). Thus significant proportion of children of primary and secondary school age seems to be engaged as child labourers in the country. Some of the children engaged in child labour, work in paid jobs, on the farm while others work as house help or domestic servants (Nwokoro 2011). 
This trend poses a serious threat to the educational, emotional and health condition of children affected. Most of the children affected seem to perform poorly academically while others face possibility of dropping out of school (UNICEF 2005). Apart from this, some of the child labourers are exposed to long hours of work in dangerous and harsh physical conditions, making them vulnerable to health hazards. The combination of the perceived educational limitations and health risks child labourers face could have implications on their future and by extension that of the entire society.

Researchers and scholars investigating this phenomenon mostly direct their attention to issues such as relationship between child labour and schooling. Their study found that child labour deters children from schooling and have negative effect on academic performance of child labourers (Amao, Oni, Yusuf and Omonona 2014), child labour situation in artisanal mines and quarries (ILO, 2011). The study investigated socio-demographic attributes child labourers face including their life conditions in mines in Ogun State and found that most child labourers were between age ranges of 5-10 years and mostly boys as their major source of income was working in the mines; determinants of child labour in rural Nigeria (Badmus 2008). The study seem to suggest that poverty is one of the major causes of child labour in rural areas; Child Labour Dynamics and Implications for Sustainable Development in Nigeria (Okafor, 2010). The study seems to examine implication of child labour on sustainable development and found it to have adverse effect.

The gaps noted in the studies discussed above are that they appear to ignore the identification of child labour practices in rural and urban communities in Nigeria. Child labour practices in rural and urban areas may not be the same. This may be due to perceived difference in the socio-demographic characteristics and socio-cultural conditions in the two areas. Two of the obvious factors precipitating child labour seem to hinge on economic and cultural considerations (Edmonds, 2001; Nwokoro, 2001; Amao, Oni, Yusuf and Omonona, 2013 Fawole and Osungbade 2003), and the urban and rural economies and cultures also seem to vary. Consequently, rural and urban dwellers appear to respond to poverty differently. Rural people may react through farming while urban people could respond through engaging in trading, blue collar and white collar jobs. Child labour practices in rural and urban areas may therefore vary and take different forms.

Cross River state as one of the states in Nigeria may not be immune to the pervasive phenomenon of child labour. It has been noted that child labour is also one the challenges bedeviling the area as both city of Calabar and rural communities appear not to be excluded from the menace (Edet and Etim 2013). There is the need to investigate child labour practices existing both in urban and rural areas in the area so as to suggest how best the problem could possibly be controlled.

\section{Objective of the study}

The major objective of the study is to investigate child labour practices existing in rural and urban communities in Cross River State. Specifically, the study investigates the following:

a. To describe the socio-economic conditions of child labourers in Cross River state

b. To investigate child labour practices in rural and urban areas in Cross River state

c. To suggest measures for controlling child labour in the study area

\section{The concept of Child Labour}

\section{LITERATURE REVIEW}

Child labour is conceptualized variously in different countries, societies and communities base on social, cultural and legal orientations. However, what seems to be the common agreement is 
that any work that adversely affects a child's health, education, mental, physical and social wellbeing and is a threat to their future development could be regarded as child labour. According to the International Labor Organization (2005), Child Labor is "work that deprives children of their childhood, their potential and their dignity; and is harmful to their physical and mental development. It refers to such work that is mentally, physically, socially, or morally hazardous to children and or interferes with their schooling by depriving them of the opportunity to attend school, obliging them to leave school prematurely, or requiring them to combine school attendance with an excessively long and heavy workload'. The United Nations (1989) in their Convention on the Rights of the Child (CRC), see Child Labor as work that may constitute a hazard to the child, or interfere with their education; or may seem to adversely affect the child's health, be it physical, mental, spiritual or mental development. According to Nwokoro (2011) the concept of child labor as "children engaging in work for the purpose of sustaining self and or supporting family at the detriment of their proper growth and development".

\section{Child Labour Practices in Rural and Urban Areas}

Child labour practices exits in both rural and urban communities. In urban areas child labour practices appear to be numerous while the rural setups could have few. In towns and cities, one of the practices identified by investigators is street hawking. This seems to be the most popular form of child labor in towns and cities in Nigeria. Estimates indicate that 20 per cent of children between the ages of 10 and 14 are involved in child labor and street trading. As such, children have come to make-up about 17 per cent of Africa's Labor force (Ekpenyong and Sibiri 2011). This is certainly the case in Nigeria in general and the South-East zone in particular where such children hawk a wide range of cheap articles, edibles and products such as sachet water, plantain chips, bread, biscuits, okpa, ugba, fruits, vegetables, wears, newspapers etc on the streets and along the roads especially at damaged portions of the roads where motorists and other road-users are constrained to slow down due to the bad condition of such roads.

Another child labour practice that seems to be dominant in urban areas exists in the form of house-helps or domestic servants (Okafor 2010). Under this practice, children of the poor from rural areas come under custody of the rich or relatively privileged people from cities who promise to train and educate these children. Upon arriving in the city, these children are later turned into house-helps or domestic servants, taking care of all domestic chores including laundry and kitchen duties. To Okafor (2010) "Children in domestic service in Nigeria can be in several forms. Firstly, it may include or involve children from other families, parents, or another society employed by certain people which are believed to be wealthy and sometimes of modest income. The child is expected to work as 'house-help,' prepares breakfast and serve it to members of the household. In addition, he/she later does the remaining jobs in the evenings and late in the night"

Again, child labour practice could be in form of paid jobs (ILO, 2011). This practice operates in situations where children are employed to work in dehumanizing conditions that are detrimental to their health and education. It has been observed that most of the children from poor background are recruited to work as artisans or blue collar jobbers in mines and quarries in the western Nigerian states of Ogun and Oyo. Consequently, most of the children find it difficult to attend school after work due to exhaustion.

Another child labour practice in urban areas is sales/shop operator (Nwokoro 2011). In this practice, business people or traders from towns or cities take some of the children in villages to their shops and business centers to serve for a number of years, with the promise to assist 
them establish their personal business outfits at the expiration of their service period. In many cases, such children are exploited as they are merely used and dumped on the basis of one accusation or the other.

In rural communities, child labour practices appear hinged mainly on the use of children in the agricultural sector. Child labour in agriculture is a global phenomenon and is found in all regions of the world including Nigeria. Seventy percent of all child labourers work in agriculture in rural areas. As majority of work in rural areas is agricultural, nine out of ten working children in rural areas are engaged in agriculture or similar activities. Though agriculture takes place mainly in a rural setting, urban agriculture, which is labour intensive and occurs on small plots of land, is found in both developing and developed countries. An estimated 200 million farmers work part time in urban agriculture. Thus, agricultural child labourers may also be found in urban areas (Edet and Etim 2013; ILO, 2006).

\section{Measures for controlling child labour}

Few measures have been put in place to control the scourge of child labour in Nigeria. One of the measures include constant raid of child labour sites by law enforcement and arrest of culprits and halting of the child labour activities in the locations (ILO 2011).

Another measure is the establishment of National Agency for Prohibition of Trafficking in Persons and Other Related Matters (NAPTIP) which came into being on the 8th August, 2003. The Agency is the Federal Government of Nigeria's institutional response to addressing the scourge of trafficking in persons in Nigeria and its attendant human abuses in its entire ramification. In the process of implementing its policies, the agency have been able to reduce proportion of children trafficked internally and externally for child labour. In their report, NAPTIP said they stopped 92 children trafficked for child labour between May and July, 2010 (NAPTIP Annual Report 2010).

Other measures include enforcement of series of labour laws aimed at protecting children, young persons and minors at work. It also includes other codes of conduct and regulations guiding occupational health, safety and welfare for the production of working children (FMLP, 2003). These legislations include:

a. The Labour Act, L1, 2004.

b. The Factory Act, F1, 2004.

c. The Trade Unions Act, T8, 2004.

d. The Employee Compensation Act, 2010.

Other attempt to reduce child labour includes organization of national policy and sensitization workshop on Child Labour in Nigeria by FMLP and the Federal Ministry of Youth Development (FMYD) in collaboration with International Labour Organization (ILO) and the United Nations Children's Fund (UNICEF) in 1998. One of the recommendations of that workshop was that Nigeria should become ILO-IPEC member country, which was accepted. Based on the recommendations of that workshop, the FMLP responded positively and made further contributions to the fight against the scourge of child labour in Nigeria, amongst which include withdrawal of children as bus conductors, training of officers to monitor child labour cases, and sensitization of the National Assembly to see and act on worst forms of child labour in the country. 


\section{Marxist Theory}

\section{THEORETICAL FRAMEWORK}

Marxist theory originates from ideas of Karl Marx and Frederick Engels (1963). The central argument of the theory hinges on exploitation of the labourers by privileged dominant class. Marxist theory assumes that society is always in perpetual state of conflict between the owners of resources and workers who compete over economic resources which are scarce. The competition and struggle for economic resources have made conflict inevitable in society. Thus, conflict is seen as a normal happening in society rather than an abnormal occurrence. Marx emphasizes that economic interest rather norms and values are central in the analysis of conflicts in society. Marxist analysis maintains that at any point in time, dominant group will use labour to their own advantages to pursue their economic interest.

Thus, child labour practices in Nigeria could be viewed from the perspective of exploitation of underprivileged class (children) for economic interest of the privileged dominant class. In urban areas child labour is perpetuated to further economic interest of the perpetrators as children are engaged to hawk on streets, work in mines/quarries, trading shops and generate income for resource owners. In rural communities, agriculture is the main economic activity and most of the child labour activities occur on the farm as children are exploited on the farm by working in dehumanizing conditions for farm owners. Therefore in both areas it appears economic interest is the chief determinant of child exploitation.

\section{Research Design}

\section{METHODOLOGY}

This paper adopted survey design. This is because the design allows the researcher to collect data from large samples and is suitable for use of statistics for analysis and generalization of findings.

\section{Study Area}

Cross River was created on May 27, 1967 from the former Eastern Region, Nigeria. Its name was changed to Cross River State in the 1976 state creation exercise from South Eastern State (Nwabueze 1982). Its capital is Calabar, and its name is derived from river Cross (Oyono), which passes through the state. Cross River State is a coastal state in South-South Nigeria, which passes through the state. It is located in the Niger Delta region of the country with population of 3,737,517 according to 2016 National Population Census (NPC) and occupies 20,156 square kilometers. It shares boundaries with Benue State to the north, Ebonyi and Abia States to the west, to the east by Cameroon Republic and to the south by Akwa-Ibom and the Atlantic Ocean.

Its major towns are Akamkpa, Biase, Calabar South, Ikom, Igede, Obubra, Odukpani, Ogoja, Ugep, Obudu, Obanliku, Akpabuyo, Ofutop, Iso-bendeghe, Danare, Boki, Yala, Bendeghe Ekiem, Etomi, and Ukelle. The State is composed of several ethnic groups, which include the Efik, the Ejagham, Yakurr, Bette, Yala, Igede, Ukelle and the Bekwarra. The Efik language is widely spoken in the southern part of Cross River State, especially in Calabar Municipality, Calabar South and Odukpani while Ejagham language is the most widely spoken language in Cross River State.

There are also the Yakurr/Agoi/Bahumono ethnic groups in Yakurr and Abi LGA, while the Mbembe are predominantly found in Obubra LGA. Further up the core northern part of the state are several sub-dialectical groups, among which are Etung, Olulumo, Ofutop, Nkim/Nkum, Abanajum, Nseke and Boki in both Ikom, Etung and Boki LGAs. Also, the Yala/Yache, Igede, 
Ukelle, Ekajuk, Mbube, Bette, Bekwarra and Utugwang people are found in Ogoja, Yala, Obudu and Obanliku Local Government Areas.

\section{Population}

Population of the study includes staff of Ministry of Women Affairs, Department of Social Welfare and all child labourers (both male and female) residing in both rural and urban communities in Cross River State.

\section{Sampling Technique and Procedure}

The sampling technique involved first, a purposeful selection of Calabar as an urban community and Abochichie community in Yala Local Government Area to represent rural communities. Afterwards, Cluster random sampling technique was used to select 100 respondents each from Calabar Municipal and Calabar South LGAs, totaling 200 respondents. This technique was chosen because the researchers do not have a list of child labourers in the study area. In the process of selecting respondents, the researchers went to Calabar and Abouchichie in Bekwara Local Government Areas and compiled a list of children subjected to child labour and from the list they selected the first 120 (in Calabar) and 80 (in Abouchichie) to even the numbers for the study.

Purposeful sampling method was also used to select key informants. In this process, the researchers identified offices in charge of child labour such as social welfare in Abouchichie and Ministries of Education and Women Affairs. In these offices at least one (1) senior official was selected for the interview and 2 child workers in the two areas.

\section{Method of Data Collection}

Data for the study was collected by use of questionnaires and Key informant interviews. For the questionnaires, data collection procedures involved the researchers and their research assistants visiting the respondents personally for administration of the questionnaires. The assistant had the tasks of distribution and interpretation of the questionnaires to the respondents. After the administration and distribution, the questionnaires were collated for analysis. For key informant interviews, the researchers visited the key informants discussed the aims of the study with them and booked appointment for the interview. Data was collected through use of tape recorders and phones.

\section{Method of Data Analysis}

For questionnaires, analysis of data involved the use of descriptive statistics. Percentages were used to analyze the opinions of respondents regarding child labour practices in rural and urban areas in Cross River state. For key informant's interview, the researchers transcribed the responses of the key informants and discussed them on the basis whether they collaborate or contradict data from questionnaires.

\section{RESULTS AND DISCUSSION}

This section is devoted to the presentation and analysis of data under the following headings; socio-demographic characteristics of respondents, child labour practices in Rural and Urban communities in Cross River State and measures to control child labour in urban and rural communities in the state. 
Table 5.1: Socio-Demographic Data of Respondents

\begin{tabular}{llc}
\hline \hline Variable & Frequency & Percentage \% \\
\hline (a) Age (Years) & 66 & 33.0 \\
$5-11$ & 134 & 67.0 \\
$12-17$ & $\mathbf{2 0 0}$ & $\mathbf{1 0 0}$ \\
Total & & \\
& & \\
(b) Sex & 97 & 48.5 \\
Male & 103 & 51.5 \\
Female & $\mathbf{2 0 0}$ & $\mathbf{1 0 0}$ \\
Total & & \\
& & 16.0 \\
(c) Educational Background & 32 & 74.0 \\
Not Attending school & 168 & $\mathbf{1 0 0}$ \\
Attending School & $\mathbf{2 0 0}$ & \\
Total & & 24.0 \\
(d) Present Educational level & & 76.0 \\
Primary & 48 & $\mathbf{1 0 0}$ \\
Secondary School & 152 & \\
Total & $\mathbf{2 0 0}$ & 40.0 \\
(e) Community & & 60.0 \\
Rural & & $\mathbf{1 0 0}$ \\
Urban & 80 & \\
Total & 120 & $\mathbf{2 0 0}$ \\
\hline \hline
\end{tabular}

Source: Field Survey, 2017

Table 5.1 above presents socio-demographic characteristics of the respondents in the study area. The Table shows that the respondents in the age bracket of 12-17 years had the highest percentage of $67.0 \%$ (134), while those from the age group of 5-11 years were the least with percentage of $33.0 \%$ (66). This data appear to agree with Okafor (2010) whose findings show a "worse situation" of child labour for children of secondary school as compared to those of primary school age. Ojo and Olufemi (2013) also found what appear to be similar as most child labourers in Agege, Lagos fall within age range of 12 to 18 years. These data however seem to contradict studies by ILO (2011) mines and quarries in Ogun and Oyo states of Nigeria as children of 5-11 were found to have been used more compared to those in the age group of 1117 years.

In relation to gender, the female respondents were found to be slightly more than the males as the females had $51.5 \%$ (103) while the males had $48.5 \%$ (97). This finding seems to corroborate 0jo and Olufemi (2013) studies which show more girls working as child labourers compared to the boys in Agege in Lagos state. This none the less contradicts studies by ILO (2011) who found more boys than girls working in mines and quarries in Oyo and Ogun States. This finding could be due to the gender roles in our society which culturally designate labour intensive functions to the boys than the girls and equally the role played in the different facets of labour outlined as quarries typically demands the indefatigable traits often perceived and believed to be dominant in the masculine gender.

Base on educational background, majority 74.0\% (168) of the respondents were attending school while few $16.0 \%$ (32) of them were not attending school. This study appears to confirm 
ILO (2011) postulation that most of the child labourers currently attend school contrary to the popular perception that child labourers do not attend school. But most of them seem to combine schooling with work which could adversely affect their academic performance (Okakor 2010).

The present educational level of the respondents shows that most of them were in secondary school with $76.0 \%$ (152) while few were in primary school level with $24.0 \%$ (48). This data seem to corroborate findings by Okafor (2010) who showed that in Nigeria, approximately 53 per cent of children eligible for primary education are subjected to child labour while an estimated 81.12 per cent of children qualified to be in secondary school are actually not schooling or seem to be combining work with schooling due child labouring activities.

Based on the residing community, most of the respondents were in urban areas with $60.0 \%$ while the rest resided in rural communities with $40.0 \%$ (80).

Table 5.2: Work engaged in by Child labourers in Rural and Urban Communities in Cross River State

\begin{tabular}{lcc}
\hline \hline Urban & Frequency & Percentage \% \\
\hline Street hawking & 37 & 30.8 \\
Car washing & 10 & 8.3 \\
Domestic work & 42 & 35.0 \\
Bus conducting & 11 & 9.2 \\
Blue-collar labouring & 2 & 1.7 \\
Plate washing & 6 & 5.0 \\
Shop/store operator & 12 & 10.0 \\
Total & $\mathbf{1 2 0}$ & $\mathbf{1 0 0}$ \\
& & \\
Rural & 17 & 21.3 \\
Palm wine Tapping/sale & 58 & 71.4 \\
Farming & 5 & 6.3 \\
Kiok Operation & $\mathbf{8 0}$ & $\mathbf{1 0 0}$ \\
Total &
\end{tabular}

Source: Field survey, 2017

Table 5.2 above presents work engaged by child labourers in rural and urban areas in Cross River state. The Table shows that in the urban areas, the most common child work is domestic work with $35.0 \%$ (42) followed by street hawking with 30.8\% (37) and Shop/store operating $10.0 \%$ (12) while the least work is blue-collar labouring with $1.7 \%$ (2) followed by plate washing in restaurants with $5.0 \%(6)$. Other child work identified include car washing with $8.3 \%(10)$, bus conducting with $9.2 \%$ (11). In rural communities, the common child labour activity is farming with $71.4 \%$ (58) while the least work is kiosk operating with $6.3 \%$ (5). Other work noted is palm wine tapping and sales with $21.3 \%$ (17).

Interview with a key informant who is a director in the Ministry of Women Affairs in Calabar noted that:

"...in Calabar Municipal, the child labour practices that are common include house help services, street trading, shop operating and bus conducting... though other practices such as prostitution, vulcanizing, apprenticeship, begging and factory work also exists..." 
In Abouchichie, a staff of the Department of Social works at Bekwarra Local Government Secretariat corroborated the above finding. She said:

"...in the village child labour is not so pervasive as compared to Calabar city ...the most common child labour practice is use of children in farming which most do not see as such ...this probably is due to culture which sees taking the child to the farm as a form of socialization."

The above findings seem to be similar with Bonnet (1993) who stresses that child labour practices in South Nigeria include street trading, apprenticeship, domestic service, bus conducting, shop operating amongst other. Owokoro (2011) and Okafor (2010) also to some extent appear to agree with the findings. Their studies show that most common child labour practices in urban areas is house help while Ojo and Olufemi (2013) found street hawking as a major child labour practice in towns and cities. In rural areas, most of the studies conducted agree with this finding. The studies found that common child labour practice in rural areas is the engagement of children on the farm.

Table 5.3: Opinion on whether child labourers are paid for the work in Rural and Urban Areas in Cross River state

\begin{tabular}{lcc}
\hline \hline Area & Frequency & Percentage \% \\
\hline Urban & & \\
Yes & 55 & 45.8 \\
No & 65 & 54.2 \\
Total & $\mathbf{1 2 0}$ & $\mathbf{1 0 0}$ \\
& & \\
Rural & & 7.5 \\
Yes & 6 & 92.5 \\
No & 74 & $\mathbf{1 0 0}$ \\
Total & $\mathbf{8 0}$ & \\
\hline \hline
\end{tabular}

Source: Field survey, 2017

Table 5.3 seeks to inquire whether children engaged as child labourers are paid for their services. The Table has shown that in urban communities, nearly half of the respondents were paid for their services with $45.8 \%$ (55) while slightly more than half do not get paid for their services with $54.2 \%$ (65). In rural areas, the Table has indicated that most of the child labourers are not paid for their services as $92.5 \%$ (74) of the respondents attested to it while just $7.5 \%$ acknowledged payment for their services.

In an in-depth interview, a key informant stressed:

"...yeah in towns and cities, more emphasis is given to money ...people want to be paid for their work ...child labourers work in order to earn some money ...in rural areas most children engage in labour to help their families and not for money."

Child labourers in urban and rural areas also argued

"...I work as a car washer and they pay me daily based on how many vehicles I wash in a day ...most children that are working in people's houses as house helpers are not paid because I used to work in the house too..."

“....no I don't expect to get paid because I work for the family...they give me food and pay my school fees ...I have to help them too." 
This data seem to corroborate studies by ILO (2011) which found that children working in mines and quarry in Abeokuta were paid for their services. Akarro and Mtwere (2011) and ILO (2011) studies also agree with this finding by stressing that children in rural areas work for their family therefore most are not paid in cash for the services. This suggests that such work may not be paid for since it is a norm in rural areas for children to help parents on the farm.

Table 5.4: Amount to Money Paid to Child Labourers in Rural and Urban Areas in Cross River state

\begin{tabular}{lcc}
\hline \hline Area & Frequency & Percentage \% \\
\hline Urban & 12 & \\
Below $\$ 200$ & 24 & 21.8 \\
N300 - N500 & 13 & 43.6 \\
N600 - N800 & 5 & 23.6 \\
N900 - \#1200 & 1 & 9.1 \\
N1300 and above & $\mathbf{5 5}$ & 1.9 \\
Total & & $\mathbf{1 0 0}$ \\
& & \\
Rural & 4 & 66.7 \\
Below $\# 200$ & 2 & 33.3 \\
N300 - N500 & $\mathbf{6}$ & $\mathbf{1 0 0}$ \\
Total &
\end{tabular}

Source: Field survey, 2017

Table 5.4 above present amount of money paid to the child labourers in rural and urban areas in the study area. In the urban areas, the Table has shown that most of the respondents collect between $\$ 300$ - $\$ 500$ with 43.6\% (24) daily while those who receive between $\$ 1300$ and above were the least with $1.9 \%$ (1). Other amount paid to the child labourers include below N200 with 21.8\% (12), $\$ 600$ - $\$ 800$ with 23.6\% (13) and $\$ 900-\$ 1200$ with $9.1 \%$ (5). In the rural communities, the Table indicates that majority of respondents receive below $\$ 200$ with $66.7 \%$ (4) while the minority take home between $\$ 300$ - $\$ 500$ with 33.3\% (2).

An interview with key informant who is a child labourer in Calabar Municipal revealed the following:

“...they pay me 100 naira daily when I work with builders on the site ...sometimes I do clear the site of the building and also gather sharp sand and stones for them..."

In-depth interview with a senior staff with Ministry of Women Affairs noted:

"...that in case of children working as house help, most receive on average 10,000 naira monthly which is approximately 333 naira of daily payment..."

In a rural community in Abochichie, a key informant with Department of Social Welfare in Bekwara LGA stressed:

"...in this community people are not used to paying children for work ...most of the time, the money they collect is just for appreciation and not payment for work done ...the amount is usually small and may not even be up to 300 naira..." 
Table 5.5: People who engage Children to work as Child Labourers in Urban and Rural Areas in Cross River state

\begin{tabular}{lcc}
\hline \hline Area & Frequency & Percentage \% \\
\hline Urban & & \\
Business people/Traders & 60 & 50.0 \\
White collar jobbers & 42 & 35.0 \\
Parents & 18 & 15.0 \\
Total & $\mathbf{1 2 0}$ & $\mathbf{1 0 0}$ \\
& & \\
Rural & & \\
Parents & 64 & 80.0 \\
Relatives & 10 & 12.5 \\
Business/Traders & 6 & 7.5 \\
Total & $\mathbf{8 0}$ & $\mathbf{1 0 0}$ \\
\hline \hline
\end{tabular}

Source: Field survey, 2017

Table 5.5 presents category of people engaging children as child labourers in urban and rural areas in the study area. The Table indicates that in urban areas, people who engage children as child labourers were business people or traders with $50.0 \%$ (60) followed by people who work in offices (white collar jobbers) with $35.0 \%$ (42). Parents were the least category to engage children as child labourers with $15.0 \%$ (18). In rural areas, the Table indicates that parents had the highest percentage of the group using children to work with $80.0 \%$ (64) followed by relatives with $12.5 \%$ (10) and then business or traders with $7.5 \%(6)$.

In an interview, a key informant from Ministry of Women Affairs in Calabar noted: “...in Calabar, people who mostly use children to work for them seem to be among business people and civil servants who bring children from their villages and exploit them by way of using them in their businesses or as house helps..."

In Abouchichie in Bekwara Local Government Area, a key informant in the Department of Social Welfare revealed that:

"...in this place, children who work as child labourers do it for their parents ...parents involve their children to help them on the farm while some fetch water for the family ...working in the farm is not perceived as child labour but as a form of socialization..."

These findings seem to corroborate studies by Okafor (2010) and Edet and Etim (2013). Okafor (2010) lamented that in cities, economically privileged people such as business people or civil servants bring children from the villages and use them as domestic workers. Edet and Etim also found that in rural areas children are subjected to child labour by mostly their parents or relatives. 
Table 5.6: Suggestions for controlling Child Labour in Urban and Rural Areas in Cross River state

\begin{tabular}{lcc}
\hline \hline Area & Frequency & Percentage \% \\
\hline Urban & 72 & 60.0 \\
Execute child right laws & 33 & 27.5 \\
Prosecution of culprits & 15 & 12.5 \\
Awareness & $\mathbf{1 2 0}$ & $\mathbf{1 0 0}$ \\
Total & & \\
& & \\
Rural & 53 & 66.3 \\
Awareness & 16 & 20.0 \\
Poverty reduction & 11 & 13.7 \\
Execute laws & $\mathbf{8 0}$ & $\mathbf{1 0 0}$ \\
Total &
\end{tabular}

Source: Field survey, 2017

Table 5.6 presents suggestions for controlling child labour in urban and rural areas in the study area. The Table has shown that in urban areas, most respondents felt that child right laws should be executed with $60.0 \%$ (72) while few think there should be awareness creation with $12.5 \%$ (15). Other suggestion includes prosecution of people who engage in child labour practices with $27.5 \%$ (33). In rural areas, creation of awareness was the major suggestion with $66.3 \%$ (53) followed by poverty reduction with $20.0 \%$ (16) and execution of child right laws with $13.7 \%$ (11).

In-depth interview with key informants in Ministry of Women Affairs in Calabar suggested that:

“...in cities, most people know that child labour is evil because they have access to radio and television broadcasts, social media and often see messages from government... such people should be prosecuted ...child right laws also need to be properly implemented..."

In Bekwarra Local Government Area, a staff in the Department of Social works suggested the following:

"...child labour in rural communities occurs on the farm and most people think its normal to take a child to the farm and engage them to work since it is culturally acceptable ...there is the need to enlighten these people to know that child labour is bad and can affect the child negatively in many dimensions..."

\section{CONCLUSION}

Based on the above findings, child labour practices in urban areas in in Cross River state include domestic work, street hawking, and Shop/store operating, blue-collar laboring, plate washing in restaurant, car washing and bus conducting. In rural communities, child labour activities include kiosk operating, palm wine tapping and sales. The findings have also shown that in urban communities, nearly half of the respondents were paid for their services while in rural areas, most of the children are not paid for their services. The amount of money paid to the child labourers in the urban areas ranges mostly between $\$ 300$ - \$500 daily while children who receive between $\$ 1300$ and above were the least. In the rural communities, majority of respondents receive below $\$ 200$ while the minority take home between $\$ 300-$ \$500. The category of people engaging children as child labourers in urban areas, are mostly business people or traders followed by white collar jobbers while parents were the least category to engage children as child labourers. In rural areas, parents are the group that uses 
children as child labourers the most while business people or traders are the least to engage children to work. Child labour practices in urban areas involve exploitation of children by privileged people in urban areas thus confirming the assumptions of Marxist theorists. In rural communities, child labour happens on the need to help parents and not solely for economic reasons which seem to invalidate propositions of Marxists.

The suggestions for controlling child labour in urban areas include mostly execution of child right laws while creation of awareness was the least suggestion. Other suggestion includes prosecution of people who engage child into child labour. In rural areas, creation of awareness was the major suggestion followed by poverty reduction and execution of child right laws.

\section{RECOMMENDATIONS}

Based on the conclusion drawn from the findings, the following recommendations are made in order to control the phenomenon of child labour in rural and urban areas in Cross River state:

a. There should be proper implementation of child right laws in urban areas. This could enable stakeholders such as law enforcement agents, NGOs and government agencies and parastatals to intervene, control, arrest and prosecute people engaging children to work as child labourers and subsequently control the scourge in the study area.

b. In rural areas, intensive awareness should be created to ensure that rural dwellers are enlightened to know that involving children in child labour activities such as farming for longer period of time constitutes a child labour practice. This could help in controlling the phenomenon in rural communities.

c. Government should evolve poverty eradication programmes that will truly be beneficial to parents and by doing so could help control situations where parents involve their children in child labour for economic reasons.

\section{References \\ Akarro, R. R. J. and Mtweve, N. A. (2011). Poverty and its Association with Child Labour in Njombe District in Tanzania: The Case of Igima Ward. Current Research Journal of Social Sciences 3(3):199-206.}

Amao, I. O., Oni, O. A., Yusuf, S. A. and Omonona, B. T. (2013). Determinants of Child Labour and Schooling in Rural Northeastern Nigeria. Journal of Rural Economics and Development, 19:1

Badmus, M. A. (2008). Incidence and Determinants of Child Participation in paid employment in rural Nigeria: An unpublished Ph.D Thesis. Department of Agricultural Economics, University of Ibadan, Ibadan, Nigeria.

Bass, L. E. (2004). Child Labour in Sub-Saharan Africa. Lynne: Rienner Publisher.

Bassey, E. M., Baghebo, M. and Otuu, C. A. (2012). Child Labour In Nigeria And Its Economic Implications: A Case Study Of Calabar Municipality. Research on Humanities and Social Sciences, Vol. 2, No.9, 2012

Basu, K. (1999). Child labor: Causes, consequences, and cure, with remarks on international labor standards. Journal of Economic Literature. 37 (September): 1083.1119.

Benjamin Obi Nwabueze (1982). "A Constitutional History of Nigeria". C. Hurst and Co LTD, UK.

Edet. G. E. and Etim, N. A. (2013). Child Labour In Agriculture among Poor Rural Households: Some Issues and Facts. European Journal of Physical and Agricultural Sciences. Vol. 1 No. 1, 2013.

Ersado, L. (2003). Child Labor and Schooling Decisions in Urban and Rural Areas: Cross-Country Evidence. Paper prepared for presentation at the American Agricultural Economics Association Annual Meeting, Montreal, Canada, July, 27-30, 2003. International Food Policy Research Institute, Washington, DC.

Ersado, L. (2002). Income diversification in Zimbabwe: Welfare implications from urban and rural areas. International Food Policy Research Institute, Washington, DC

Federal Ministry of Women Affairs (2003). Child Rights Act, Federal Ministry of Women Affairs - FMWA, Abuja.

ILO-IPEC (2011). Rapid assessment of the child labour situation in artisanal mines and quarries in Ogun and Oyo states of Nigeria. Geneva: International Labour Organization. 
Marx, Karl and Friedrich Engels (1963) The Communist Manifesto. In D. Ryazanoff (ed.) New York: Russell and Russell.

Moser, C. O. N. (1996). Confronting crisis: A comparative study of household responses to poverty and vulnerability in four poor urban communities. Environmentally Sustainable Development Studies and Monographs Series, No. 8. Washington, DC: World Bank.

NAPTIP Update, (2010). National Agency for Prohibition of Trafficking in Persons (NAPTIP) Annual Report (MayJune, 2010).

National Bureau of Statistics (2009). "Annual abstract of statistics", NBS, Abuja

Nkamelu, G. B. (2009). Determinants of Child Labour and Schooling in the Native Cocoa Households of Cote D'Ivoire, Research Paper 190; African Economic Research Consortium, Nairobi: Kenya.

Nwokoro, C. N. (2011). The Challenge of Child Labor to the Achievement of MDG2: Case Study of South-East Nigeria. Unpublished Master's Thesis in Human Development and Food Security, Department Of Economics, Universita” Degli Studi “Roma Tre” Rome.

Ojo, M. \& Olufemi D. (2013). A Sociological Investigation of The Determinant Factors and The Effects of Child Street Hawking in Nigeria: Agege, Lagos State, Under Survey. International Journal of Asian Social Science, 3(1):114-137

Okafor, E. E. (2010). Child Labour Dynamics and Implications for Sustainable Development in Nigeria, Journal of Sustainable Development in Africa, 12.5:9-21.

United Nations Children's Fund - UNICEF (2005). “The state of the world's children - Childhood under threat. United Nations Children's Fund - UNICEF (2006). Information sheet on child labour, Nigeria.

\section{General Instruction: Please tick $(\checkmark)$ where appropriate \\ Section A: Socio-Demographic Information}

1. Age:

2. Sex: ( ) Male ( ) Female

3. Educational Background:

4. Educational Level:

5. Community of residence:

Section B: To investigate child labour practices in rural and urban areas in Cross River state

6. What kind of work do you do as child?

7. Do you receive pay for the work? Yes ( ) No ( )

8. If Yes how much do you receive:

9. Who engages you to work?

\section{Section C: Measures for controlling child labour in rural and urban areas in Cross River state}

10. Are you aware of measures put in place to control child labour in the community? Yes ( ) No ( )

11. If Yes, List the measures: 


\section{Key Informant Interview Questions}

1. What is your name?

2. What is your rank or position in the office?

3. What are the child labour practices known to you?

4. What do you think can be done to control child labour? 